Meta

Journal des traducteurs

Translators' Journal

\title{
Types of Oral Translation in the Australian Context
}

\section{Adolfo Gentile}

Volume 33, numéro 4, décembre 1988

Symposium AILA 1987, Sydney

URI : https://id.erudit.org/iderudit/002878ar

DOI : https://doi.org/10.7202/002878ar

Aller au sommaire du numéro

Éditeur(s)

Les Presses de l'Université de Montréal

ISSN

0026-0452 (imprimé)

1492-1421 (numérique)

Découvrir la revue

Citer cet article

Gentile, A. (1988). Types of Oral Translation in the Australian Context. Meta, 33(4), 480-484. https://doi.org/10.7202/002878ar d'utilisation que vous pouvez consulter en ligne.

https://apropos.erudit.org/fr/usagers/politique-dutilisation/ 


\title{
TYPES OF ORAL TRANSLATION IN THE AUSTRALIAN CONTEXT
}

\author{
ADOLFO GENTILE
}

Victoria College, Australia

In his highly readable and extremely thought-provoking book, Grammatical Man Jeremy Campbell titles one of his chapters "The Struggle against Randomness" (Campbell $1982: 75$ ). I believe that this is an apt definition of our particular concerns with the development of text typologies. I consider it a struggle because in my view we are still grappling with the randomness of phenomena, we are still in a high-entropy state.

The aim of this paper is to attempt to make a small contribution to the typology debate by outlining some observations of certain data which form part of the random world of texts ; these data are different in at least two ways : one, they are derived from the Australian context and two, they refer to "oral translations" which, while being unique to the Australian context, are firmly esconced in the universe of oral translations.

I intend to briefly describe the Australian context and then outline the characteristics of that context which sets it apart from others. I shall then discuss a theoretical framework for the observations which will be subsequently described and, finally, I shall venture a possible avenue for further investigation.

Oral translation is understood as the transfer of an oral message between two or more persons who do not share a language. Conference Interpreting as an umbrella term does not do justice to the varieties of interpreting which are carried out in Australia even though these can be considered varieties of simultaneous and consecutive interpretings as defined by VAN HOOF (1962), KOPCZYNSKI (1984) in (FISIAK : 1984). The bulk of interpreting in Australia is consecutive, characterized by the translation of chunks of text and requiring a change in language direction at each interpretation. This does not mean that simultaneous interpretation is non-existent, on the contrary, it must be added that it is carried out in contexts far removed from conference rooms equipped with booths; simultaneous is usually accomplished in the chuchotage mode in such varied settings as mental health and law, the one important difference being that it is done in both language directions or is sometimes used on the same occasion as consecutive. So much for the varieties of interpreting mode.

The protagonists in these situations are always an English speaker and a speaker of another language, one of the languages spoken in Australia by those who have migrated here over the past forty years or by the peoples who were here before white settlement. These languages are not the "traditional" languages of interpreting, viz. French, German, Russian, etc. but are more likely to be Greek, Italian, Vietnamese and Turkish. This is a crucial point to be kept in mind for later discussion as it illustrates the problems created by "cultural affinity" considerations. A further aspect of this macrocontext is the fact that interpreting is used in most "naturally occurring" situations over a person's lifetime, this means that it is an integral part of a person's relationship with the community at large, of that person's access to services available to the Englishspeaking population and of that person's obligations as a member of the community, e.g. in taxation, legal matters, voting rights, etc. Interpreting in this context is not re- 
garded as a status symbol but is a vehicle for the achievement of social justice goals encapsulated by the Government in the concepts of "access" and "equity". (This does not, of course, imply that these goals are being achieved.)

So the modes, the protagonists and the macro-context of interpreting in Australia set it apart from, but are on the same continuum as interpreting in the rest of the world (Britain and Israel are experimenting with similar systems to our own).

The theoretical frameworks for the development of text typologies which have been utilized up to this point reflect a move from the consideration of the text qua text to the text as an instance of communication. They represent a shift in focus from the sender (S) to the receptor (R), Wilss categorizes the current approaches as belonging to the general area of text linguistics and having as their focus

communicative (contextual) text research (communicative text theory) (Wilss $1982: 114$ ).

The basic consideration here is that one is dealing with ACTUAL as opposed to VIRTUAL texts - the "linguistique de la parole". Thus far one is speaking of any text, any sender and any receptor. The analysis of the interpretation - i.e. the communicative impact of any text is not new and has been tackled by many including Peirce, Barthes, and more recently Eco. Among the questions being asked here is "How does the surface structure of a text elicit the cooperation of the receptor and what is required in terms of cooperation?" This is obviously an oversimplification but it is useful in that it sets up a contrast when one is talking not of "any" text but a text to be translated. In the latter instance the translator emerges as an active participant in a triad, another loop in the communication circuit; the translator must "mediate interlingually between members of different language communities" as Wilss (1982:118) puts it.

It seems that, in general, translation - relevant typologies have emerged which could be called function-oriented typologies and/or transfer-method oriented typologies ; these labels describing the main point of departure of these typologies. The text types are described variously as "Informative, Expressive, Operative" (Reiss 1976) ; Exposition, Argumentation, Instruction (Hatim 1984) ; Representational, Appellative, Expressive (K. Bühler 1965) ; Overt and Covert Translation (House 1977). The latter also fits in the category of transfer-method oriented typologies as does that of $\mathbf{H}$. Bühler (1979). It will be noted that the orientation of these typologies does not make them mutually exclusive, in fact it is through the analysis of function that the transfer method or strategy should emerge. The above list is certainly not exhaustive and points to the need to further refine the concepts to a more generalized working hypothesis about text function since even if this is established, it only provides the translator with a starting point for textual analysis and does not cater for a multiplicity of functions within one text, for example ; furthermore, it is not clear whether the majority of authors make a distinction between oral and written texts, or whether such a distinction does, indeed, need to be made.

Having traversed much ground much too quickly I now intend to present some typical communication situations from the Australian context to see whether the application of the above typologies is possible.

It must be indicated at the outset that in Australia the interpreter is always physically present in the communication situations. This has obvious and relevant implications ; some of which are : not all participants treat the interpreter as a mouthpiece, but endeavour to involve him/her in the actual communication situation, e.g. the nonEnglish speaker (NES) may ask the interpreter his/her opinion of the doctor or institution in the middle of a consultation, or he/she may enquire about the interpreter's opinion of the efficacy of the medication. The English speaker (ES) on the other hand may 
seek information about the acceptability of certain patient behaviour, may vent his/her frustrations audibly not expecting them to be translated. Both the NES and the ES may speak in the third person because there is a third person or to distance themselves from an unpleasant, annoying or embarrassing utterance.

It is clear then, that as a physical entity the interpreter is forced not only to analyze the text receptively but must also guard against becoming the receptor, something which invariably changes or shifts the function away from the interlocutors who are responsible for the communication function.

Another important difference, apart from physical presence, is that although there may be commonality of purpose which brings the interlocutors together, there is often little else in common between them. A conference of, say, civil engineers, meeting to discuss the latest developments in pre-stressed concrete technology would have its own "culture" i.e. shared interests, comparable levels of education, similar goals, a degree of shared terminology, even if only at the level of mathematical concepts. In the case of a person seeing a lawyer about an out-of-court settlement of an insurance claim, we have a curious interplay of factors which tax the interpreter and create difficult transfer problems. Firstly the macro-contexts of the law, its functions and its modus operandi will be different. This creates certain expectations from the lawyer and the client in turn, which may not be fulfilled in the course of the interview. The lawyer might expect from the client tacit approval of the way he is handling the case, the client on the other hand may have expectations of the lawyer which go beyond what a lawyer can do, in a legal sense, in the Australian system. In matters of probate for example, different cultures deal with the estate of the deceased in different ways, some guaranteeing a proportion of that estate to the immediate family, others relying solely on the contents of the last will and testament. The interpreter in these cases must again analyze the text receptively and also carry it adequately into the target language, adequately meaning that as far as possible he/she has to adjust for systemic differences in the cultures in question. If necessary and in extreme cases he must intervene to explain such differences if this is the only way that communication can take place. There is therefore a gap between $S$ and $R$ which is determined not so much and not only by the language differences but also by cultural and ethnological factors.

Another important and difficult area is that where diagnosis and/or therapy is dependent upon language itself, or more precisely where language is a manifestation of a pathological condition whose diagnosis depends on an assessment of language patterns and content. This we have in mental health, speech therapy and gerontology. In speech therapy, especially therapy following a cardio-vascular accident which has precipitated a stroke with impairment of the speech function, work has had to be done to develop language specific exercises to elicit the movement of certain muscles and components of the vocal apparatus in order to achieve diagnosis and rehabilitation given that in these cases one invariably, it seems, reverts to one's native tongue. Oral translation in these cases is almost useless. The area of mental health is even more problematic. In these cases the interpreter often performs simultaneous interpretation for the patient and consecutive for the doctor. Since the syntactical arrangement of speech is in these cases a vehicle of diagnosis, the interpreter has to steer a careful course between the demands of the accuracy of the translation as far as the doctor is concerned and the frequent incoherence which marks the speech of a patient in these circumstances. A similar difficulty exists in courts of law ; here language is "used" to extract information, not only information per se, but information which is consistent with the objective of whichever lawyer is questioning a witness. It is always said that interpreting in courts must be more precise - but it is not the interpreters who say it! To have validity of law, testimony must be 
rendered as accurately as possible, however this is conceived by many judges as a wordfor-word translation. The interpreters know that this is nonsense, so they promptly ignore the judge's directives, only the occasional interpreter, in a state of exasperation has proceeded in this fashion much to the amusement of the court. This exemplifies not only the problems of the interpreter, but also the ignorance of monolinguals in these matters and leads me to my final illustration, i.e. the difficulties which stem from culturally specific therapy methodologies or discourse patterns of particular professions. One example will suffice. Social workers and clinical psychologists, to name two professions, are trained in the non-directive counselling technique, this often involves the repetition of an answer by a client in the question form to allow the client, in the long term, to come up with his/her own solutions to problems. This may be tolerated by ES (and it is no accident that this technique was developed by an ES), but it often leaves clients of other cultural backgrounds perplexed to say the least, the natural scapegoat is the interpreter. Mediation takes on a new meaning. Time does not permit a more detailed examination of other texts or communication situations and it must be stressed that the above examples are but the tip of the iceberg.

What of translation typologies?

As I hinted above, the function-oriented typologies would be only partially useful to the interpreter in the Australian context. The main reason is that they lack the explanatory power to cater for some of the characteristics illustrated. Even though one could say that at a macro-level they could distinguish between the function of diagnosis/treatment as against that of persuasion, for example, the former function could include the latter in some cases, given the cultural/cognitive parameters described above.

In conclusion, it may be fruitful to proceed, in our context, with research on a typology based on textuality standards as outlined by de Beaugrande and Dressler (1981), especially those standards which relate more to the receptor than to the text itself and precisely those of acceptability, informativity, situationality and intertextuality. A possible approach might be to postulate relative levels of presence of these standards, having first clarified some ideas on the relationship between text and discourse by the examination of actual communication situations within a given frame of reference. In other words the textuality standards could become second order variables within functional frameworks.

\section{BIBLIOGRAPHY}

BEAUGRANDE, R. de \& W. DRESSLER (1981) : Introduction to Text Linguistics, London, Longman. BÜHLER, H. (1979) : "Suprasentential Semantics and Translation", in META, 24:4, pp. 451-458.

BÜHLER, K. (1965) : Sprachtheorie, Stuttgart.

CAMPBELL, J. (1982) : Grammatical Man, Harmondsworth, Penguin Books.

CONTE, M.E. (1977) : La Linguistica testuale, Milano, Feltrinelli.

COULTHARD, M. \& M. MONTGOMERY (1981) : Studies in Discourse Analysis, London, Routledge \& Kegan Paul.

DESIDERI, P. \& A. MARCARINO (1980) : Testualità e Tipologia del Discorso Politico, Roma, Bulzoni. ECO, U. (1979) : Lector in Fabula, Milano, Bompiani.

FISIAK, J. (Ed.) (1984) : Contrastive Linguistics : Prospects and Problems, Berlin, Mouton.

GADDIS ROSE, M. (1981) : Translation Spectrum, Albany, SUNY Press.

GOFFMAN, E. (1975) : "Replies and Responses", in Documenti di Lavoro e Prepubblicazioni, Centro Internazionale di Semiotica e di Linguistica, Università di Urbino, $\mathrm{n}^{\circ} 46$ and 47.

HATIM, B. (1984) : "A Text Typological Approach to Syllabus Design in Translator Training", in The Incorporated Linguist, 23:3

HOUSE, J. (1977) : A Model for Translation Quality Assessment, Tübingen.

LEFEVERE, A. (1977) : Translating Literature; the German Tradition, Assen NL, Van Gorcum.

OPOLSKA KOKOSZKA, B. (1987) : "Pour un modèle interdisciplinaire de la traduction", in Babel, vol. XXXIII, no 1 . 
POSNER, R. (1982) : "L'analyse pragmatique des énoncés dialogués", in Documenti di Lavoro e Prepubblicazioni. Centro Internazionale di Semiotica e di Linguistica, Università di Urbino, $\mathrm{n}^{\circ} 113$. REISS, K. (1976) : Texttyp und Übersetzungsmethode, Kronberg Ts, Scriptor Verlag.

VAN DIJK, T. (1977) : Text and Context. Explorations in the Semantics and Pragmatics of Discourse, London, Longman.

WILSS, W. (1982) : The Science of Translation, Tübingen, Gunter Narr Verlag.

YOUNG, R. (1981) : Untying the Text, Boston, Routledge and Kegan Paul. 